\title{
Immunolabeling analysis of biosynthetic and degradative pathways of cell surface components (glycocalyx) in Paramecium cells
}

\author{
Matthias Flötenmeyer, Massoud Momayezi and Helmut Plattner ${ }^{1)}$ \\ Faculty of Biology, University of Konstanz, Konstanz/Germany
}

Received July 17,1998

Received in revised version September 29, 1998

Accepted October, 9, 1998

Cell surface - glycocalyx - immuno-labeling Paramecium

Biosynthetic and degradative pathways of glycocalyx components are largely unknown in Paramecium and in some related parasitic protozoa. We isolated cell surface (glyco-)proteins, i.e., surface antigens (SAg) and used them in the native (nSAg) or denatured (dSAg) state to produce antibodies $(\mathrm{AB})$ for immunolocalization by confocal imaging and by quantitative immunogold EM-labeling of ultrathin sections or of freeze-fracture replicas. Antibodies against nSAg or dSAg, respectively, yield different labeling densities over individual structures, thus indicating biosynthetic or degradative pathways, respectively. We derive the following biosynthetic way: $E R \rightarrow$ Golgi apparatus $\rightarrow$ non-regulated/non-dense core vesicle transport $\rightarrow$ diffusional spread over non-ciliary (somatic) and ciliary cell membrane. For degradation we show the following pathways: Concentration of $\mathrm{nSAg}$ in the cytostome $\rightarrow$ nascent digestive vacuole $\rightarrow$ mature vacuoles $\rightarrow$ release of dSAg at cytoproct, with partial retrieval by "discoidal vesicles". A second internalization pathway proceeds via coated pits ("parasomal sacs") $\rightarrow$ early endosomes ("terminal cisternae") $\rightarrow$ digestive vacuoles. Dense packing of SAg in the glycocalyx may drive them into the endo-/phagocytic pathway. Still more intriguing is the site of nSAg integration into the cell membrane by unstimulated exocytosis. We consider unconspicuous clear vesicles relevant for nSAg export, probably via sites which most of the time are occupied by coated pits. This could compensate for membrane retrieval by coated pits, while scarcity of smooth profiles at these sites may be explained by the much longer time period required for coated pit formatiou as compared to exocytosis.

\footnotetext{
1) Prof. Dr. Helmut Plattner, Faculty of Biology, University of Konstanz, P. O. Box 5560, D-78434 Konstanz/Germany, Fax: ++7531882245 .
}

\begin{abstract}
Abbreviations. AB Antibody/antibodies. - ARG Autoradiography. $\mathrm{Au}_{6,10} 6$ or $10 \mathrm{~nm}$ gold particles. - BSA Bovine serum albumin. CLSM Confocal laser scanning microscopy. - dSAg Denatured SAg. - DTT Dithiothreitol. - EM Electron microscope. - FITC Fluorescein isothiocyanate. - FRL Freeze-fracture replica labeling. GPI Glycophosphatidyl inositol. - i-Ag Immobilization antigen. nSAg Native SAg. - pA Protein A. - PAGE Polyacrylamide gel electrophoresis. - PBS Phosphate-buffered saline. - PL-C Phospholipase C. - PLT Progressively lowering temperature (method). - SAg Surface antigen. - SDS Sodium dodecylsulfate.
\end{abstract}

\section{Introduction}

Among the glycoproteins of the glycocalyx in the ciliated protozoan Paramecium, a major portion is known as immobilization antigens (i- $\mathrm{Ag})$, since antibodies $(\mathrm{AB})$ against different genetic types cause immobilization [10]. Depending on the type of surface antigens (SAg) present, cells are assigned to different serotypes [57]. Among SAg there are groups of $\leq 40-45 \mathrm{kDa}$ and 220 to $>300 \mathrm{kDa}[1,2,14,24,43,51,53]$. Not only the large surface (glyco-)proteins constitute i-Ag anchored by a glycophosphatidyl inositol (GPI) residue $[9,15$, $17,18,22]$, but also the low molecular SAg forms [11].

The physiological function of SAg is much less known in Paramecium $[12,18]$ than in some parasitic protozoa (see below and "Discussion"). In Paramecium, too, these proteins are under strict genetic control [52] and they undergo considerable turnover $[16,55]$.

Our aim was not to discriminate between individual glycocalyx components, but rather to explore so far unknown general pathways. Therefore, we refer to the antigens exposed on the surface of unpermeabilized cells as "surface antigens", SAg. Since so far neither the biosynthetic nor the degradative pathway could be established $[3,18,21,55]$ we now try to obtain some basic information by the following strategy (considering the current impossibility to perform precise time 
sequence studies with $\mathrm{AB}$ against individual glycocalyx components). First, we increased the sensitivity of $A B$ labeling on the light and electron microscope (EM) level by preparing $A B$ against a collection of extracted SAg. Second, we ascertained that protein bands in extracted SAg samples correspond to protein bands in autoradiography (ARG-)gels from cells labclcd by radio-iodination in vivo. Third, we prepared $A B$ against extracted SAg in native state $(\mathrm{nSAg})$ or after denaturation $(\mathrm{dSAg})$, respectively. Denaturation was achieved by heating and reducing the numerous disulfide bridges occurring in SAg of Paramecium [17, 49]. In the cell, denaturation may occur by acidification in endocytic compartments (see "Discussion"). Fourth, we combined different light and electron microscopic analysis techniques. The two types of $A B$ used allow us to trace the biosynthetic pathway separate from the degradative pathway, mainly on the basis of transport routes established for Paramecium by the work of Allen and Fok [3, $4,5,27,28]$. We now can, for SAg components, clearly rule out some propositions in the literature, while we find rather conclusive evidence for some unexpected routes (see final summarizing scheme).

Similar glycocalyx components, like GPI-anchored surface variant antigens of some parasitic protozoa, including some ciliates $[19,20]$, are assumed to play a major role in the interaction with host cells $[23,32]$ and in producing pathogenetic effects [44]. Some important SAg components share extensive sequence or motif homologies in widely different protist species $[12,15,19]$. Therefore, we expect that our study might be seminal to further analyses with a variety of protists.

\section{Materials and methods}

\section{Cell cultures}

Paramecium tetraurelia 7S wild-type cells (obtained from CNRS, Gifsur-Yvette) were cultivated at $25^{\circ} \mathrm{C}$ in a sterile mcdium [38] to early stationary phase.

\section{Isolation of surface antigens}

We largely followed the method developed by Preer [50], as refined used by Jones [37], to prepare SAg from Paramecium. Briefly, 2 liters of cell culture $\left(\sim 10^{3}\right.$ cclls $\left./ \mathrm{ml}\right)$ were washed twice in Dryl's phosphate buffer, pH 6.8, $\left(\mathrm{NaH}_{2} \mathrm{PO}_{4}, \mathrm{Na}_{2} \mathrm{HPO}_{4}\right.$, each $\left.1 \mathrm{mM}\right)$ with $2 \mathrm{mM} \mathrm{Na} 3 \mathrm{Cit}-$ rate and $1 \mathrm{mM} \mathrm{CaCl}$ added. Then cells were kept suspended for $1 \mathrm{~h}$ in extraction medium $(12 \%$ ethanol, $7.7 \mathrm{mM} \mathrm{NaCl})$ at $4{ }^{\circ} \mathrm{C}$ and briefly centrifuged $(180 \mathrm{~g})$. The supernatant was further processed by centrifugation $\left(5 \mathrm{~min}, 20000 \mathrm{~g}, 4^{\circ} \mathrm{C}\right)$. From the resulting supernatan1, proteins were precipitated by adding solid $\left(\mathrm{NH}_{4}\right)_{2} \mathrm{SO}_{4}$, up to $75 \%$ saturation, under constant stirring on ice for $3 \mathrm{~h}$. Precipitated proteins were centrifuged $\left(15 \mathrm{~min}, 10000 \mathrm{~g}, 4^{\circ} \mathrm{C}\right)$ and resuspended in $6 \mathrm{ml}$ distilled water, and dialyzed overnight against distilled water. The resulting precipitate was discarded, while the supernatant was concentrated and lyophilized in a vacuum concentrator. Protein concentrations were determined by the Bradford method.

\section{Antibody preparation}

Isolated proteins ( $\mathrm{SAg}$ ) were dissolved in $100 \mathrm{mM}$ Tris- $\mathrm{HCl}$ buffer, $\mathrm{pH}$ 8.8. Protein was used either $(i)$ in native form (native surface antigens, $\mathrm{nSAg}$ ) or (ii) after denaturation (denatured surface antigens, dSAg). This was achieved by adding $0.5 \%$ dithiothreitol (DTT) and brief boiling, followed by alkylation ( 30 min treatment with $2 \%$ iodoacetamide). Preimmune sera were taken and checked for non-reactivity on Western blots and in immunofluorescence. For immunization, each time $130 \mu \mathrm{g}$ protein was applied in Freund's adjuvant, half by intramuscular and half by subcutaneous injection, on days 1,14 and 35 . Sera were collected after additional 14 days.

\section{Immobilization and exocytosis tests}

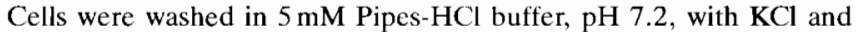
$\mathrm{CaCl}_{2}, 1 \mathrm{mM}$ each, added. To $\sim 20$ cells in $10 \mu \mathrm{l}$, the same volume of anti-SAg sera (contained in the same buffer, $+0.25 \%$ BSA) was added in increasing concentrations. After $15 \mathrm{~min}$, the percentage of immobile cells was counted in repeated assays. Any effect on exocytosis was determined in a quick test (picric acid). These tests were repeated 3 times with different batches of cells, all with the same results.

\section{Gel electrophoresis and Western blots}

Sodium dodecylsulfate (SDS) polyacrylamide gel electrophoresis (PAGE) was performed with a Laemmli-type system at gel concentrations of 5 to $15 \%$. From cells homogenized in the presence of protease inhibitors, $100000 \mathrm{~g}$ pellets and supernatants were prepared as described previously [41]. Samples were applied to gels after brief boiling, with or without preceding DTT denaturation. The sizes of markers varied between 14.5 and $94 \mathrm{kDa}$ or 97 and $584 \mathrm{kDa}$, in low or high molecular weight kits, from Pharmacia (Freiburg, Germany) or from Sigma (Deisenhofen, Germany), respectively. Gels were stained with silver or alternatively processed for Western blots and probed with anti-nSAg or anti-dSAg antibodies (AB), followed by alkaline phosphatase-tagged anti-rabbit AB (Sigma) as previously described [40].

\section{Cell surface iodination in vivo and SDS-PAGE autoradiography}

$5 \times 10^{5}$ cells in $5 \mathrm{ml}$ Pipes buffer (see above) were transferred into a propylene vial coated with iodogen (Pierce, Rockford, USA). Iodination was started by adding $500 \mu \mathrm{Ci}$ of carrier-free $\mathrm{Na}\left[{ }^{125} \mathrm{I}\right]$ from ICN (Eschwege, Germany), specific activity $=181 \mathrm{mCi} / \mathrm{ml}(1 \mathrm{Ci}=$ $\left.3.6 \times 10^{10} \mathrm{~Bq}\right)$ at $23^{\circ} \mathrm{C}$. After $15 \mathrm{~min}$, samples were removed, washed 6 times with Pipes buffer $(+0.1 \mathrm{mM} \mathrm{CaCl})$, homogenized, and subjected to SDS-PAGE and ARG using reflection TM ARG film from NEN (Köln, Germany).

\section{Immunofluorescence}

Cells were washed in phosphate buffer, pH 7.4, and injected into $4 \%$ formaldehyde in the same buffer $\left(22^{\circ} \mathrm{C}, 30 \mathrm{~min}\right)$. Then cells were pelleted and resuspended in acetone at $-80^{\circ} \mathrm{C}$. Temperature was slowly raised to $-20^{\circ} \mathrm{C}$, where cells were kept for $20 \mathrm{~min}$, before they were washed in phosphate buffer $(+50 \mathrm{mM}$ glycine) and then 3 times in buffer with $1 \%$ bovine serum albumin (BSA) added. These samples were incubated with anti-nSAg or anti-dSAg AB, followed by fluorescein isothiocyanate (FITC)-conjugated goat anti-rabbil IgG (ICN, Eschwege, Germany) for analysis by confocal laser scanning microscopy (CLSM) as previously described [40]. Controls were treated in the same way, but using preimmune sera instead of the first AB.

\section{Processing for gold labeling of ultrathin sections}

Cells were washed and fixed by injection into $4 \%$ formaldehyde supplemented with $0.25 \%$ glutaraldehyde in phosphate-buffered saline (PBS), pH 7.4, at $22^{\circ} \mathrm{C}$. Then cells were washed in PBS, incubated with $50 \mathrm{mM}$ glycine in PBS $(3 \times 10 \mathrm{~min})$, dehydrated in graded ethanol series during progressively lowering the temperature (PLT method), incubated overnight at $4^{\circ} \mathrm{C}$ in 1 part unicryl resin (Brit. BioCell Int., London) +1 part ethanol, impregnated with pure Unicryl at $4^{\circ} \mathrm{C}$ $(2 \times 3 \mathrm{~h})$ and $\mathrm{UV}$-polymerized at $-35^{\circ} \mathrm{C}$ according to the manufacturer's advice.

Ultrathin sections were washed with PBS $+0.5 \%$ BSA, incubated for $1 \mathrm{~h}$ with anti-nSAg or anti-dSAg AB (dilution 1:50), washed in PBS + BSA, and incubated with protein A (pA) which we routinely coupled to 6 or $10 \mathrm{~nm}$ large gold particles $\left(\mathrm{Au}_{6}, \mathrm{Au}_{10}\right)$, respectively. After washing with distilled water, sections were routinely stained with $2 \%$ aqueous uranyl acetate for electron microscope (EM) analysis. Values obtained from different $\mathrm{pA}$-Au batches were referred to glycocalyx labeling as a reference. 


\section{Freeze-fracture replica immunogold labeling}

Live cells were sandwiched between thin copper sheets (BalTec, Balzers. Liechtenstein), mounted on tweezers, and vigorously injected into melting propane $\left(-150^{\circ} \mathrm{C}\right)$ according to [34]. Sandwiches were inserted into a Balzers freeze-fracture unit type BAF300 (Balzers AG, Liechtenstein), fractured at $-110^{\circ} \mathrm{C}$, etched $1 \mathrm{~min}$, and replicated by $45^{\circ}$ platinum-carbon shadowing.

Subsequent freeze-fracture replica labeling (FRL) was executed according to Fujimoto [30]. Samples were thawed in PBS. To dissolve adherent cell fragments, replicas were transferred to $2.5 \%$ SDS + $30 \mathrm{mM}$ sucrose in $10 \mathrm{mM}$ Tris- $\mathrm{HCl}$ buffer, $\mathrm{pH} 8.3$. After vigorous shaking for $90 \mathrm{~min}$, replicas were washed with PBS $(4 \times 15 \mathrm{~min})$, then with PBS + BSA (30 min) and finally incubated as follows. Anti-nSAg or anti-dSAg AB, diluted 1:150 in PBS + BSA + 0.1\% $\mathrm{NaN}_{3}$, were applied overnight at $4{ }^{\circ} \mathrm{C}$. Washing with $\mathrm{PBS}+\mathrm{BSA}$ was followed by incubation with $\mathrm{pA}-\mathrm{Au}_{6}$ or $\mathrm{pA}-\mathrm{Au}_{10}$ in $\mathrm{PBS}+\mathrm{BSA}$. (BSA was $5 \%$ in all cases). After some additional PBS washes, the sandwich was fixed

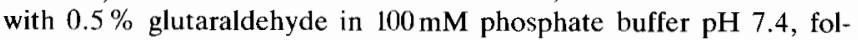
lowed by washes with distilled water and mounting on grids for routine EM analysis.

\section{Morphometry}

Gold labeling density on ultrathin sections or on freeze-fracture replicas was referred to unit area of organelles or membranes, using the hit point method (see [48]). To account for the vertical extension of the glycocalix on sections, gold grains were counted up to $50 \mathrm{~nm}$ from the cell membrane and referred to the corresponding area.

\section{Results}

SDS-PAGE, Western blot and functional analyses SDS-PAGE protein pattern of isolated SAg (Fig. 1) reveals prominent bands of $\geq 300 \mathrm{kDa}$ under non-reducing, and bands of $\leq 300 \mathrm{kDa}$ under reducing conditions, characteristic of native or denatured surface antigens (nSAg and dSAg). respectively. Other bands, particularly those of 23 to $63 \mathrm{kDa}$, are more abundant in the dSAg sample. Essentially the same type of bands are recognized after radiolabeling cells in vivo by iodogen, followed by SDS-PAGE ARG (Fig. 1).



Fig. 1. SDS-PAGE analysis with mixed low and high molecular weight markers for calibration. Silver-stained gel from isolated SAg, applied to the gel without (lane 1) or with preceding DTT treatment (lane 2). SDS-PAGE ARG of whole cell homogenates after radioiodination in vivo, after sample application to gel without (lane 3) or with preceding DTT treatment (lane 4).

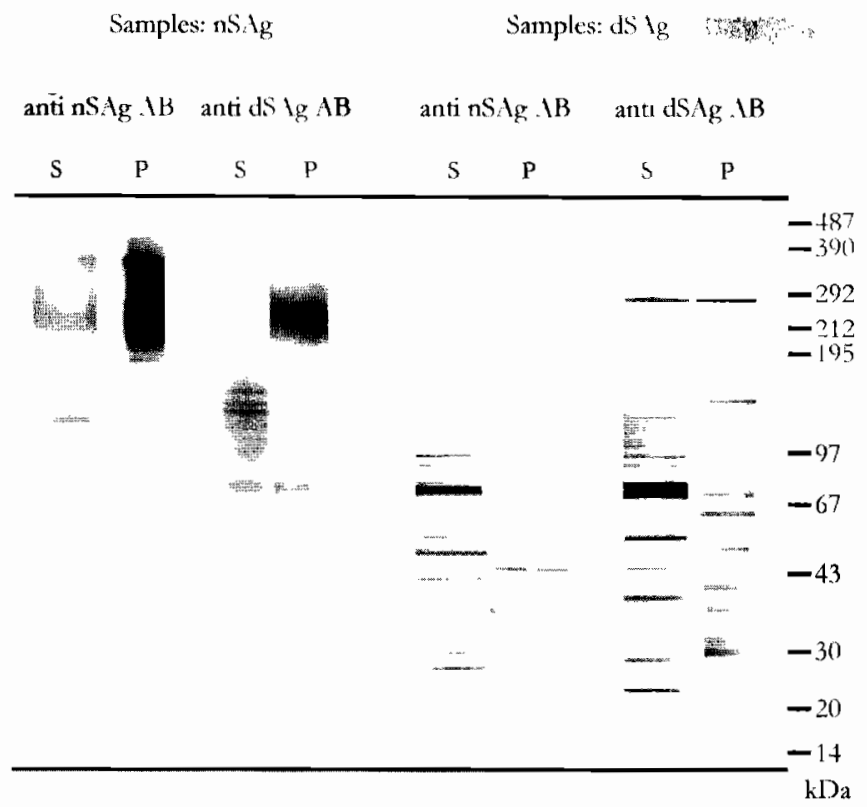

Fig. 2. Western blots obtained from SDS-PAGE from $100000 \mathrm{~g}$ supernatants $(S)$ or pellets $(P)$, applied to gels in native state (nSAg, left) or after DTT denaturation (dSAg, right), and probed with $A B$ against nSAg or dSAg, respectively.

The situation is more complex in Western blots (Fig. 2) where nSAg are compared with dSAg samples, both obtained from $100000 \mathrm{~g}$ pellets and supernatants, respectively, from whole cell homogenates, and mutually probed with anti-nSAg $\mathrm{AB}$ or anti-dSAg $\mathrm{AB}$, respectively. $\mathrm{AB}$ against nSAg prefcrentially detect large components of $\mathrm{nSAg}(\geq 243 \mathrm{kDa})$ in the pellet, whcreas they react much less with $\mathrm{dSAg}$ (in supernatant and pellet). $\mathrm{AB}$ against $\mathrm{dSAg}$ in turn are more reactive with $\mathrm{dSAg}$ (in supernatant and pellet), notably with a $76 \mathrm{kDa}$ band and a variety of smaller bands, as well as with a $267 \mathrm{kDa}$ band.

As expccted, the collection of surface proteins isolated has a wide size range. Comparison of protein staining and iodination patterns in Figure 1 confirms selcctivity of the method designed to isolate SAg (see "Materials and methods"). According to Figure 2, the two types of $A B$ used should recognize $\mathrm{SAg}$ components preferably in the native or denatured state, respectively. We performed two additional tests to establish that $\mathrm{AB}$ used recognize specifically cell surface components, including immobilization tests and CLSM immunolabeling experiments with permeabilized cells.

Anti-nSAg AB immobilize cells at much higher dilution than anti-dSAg ABs (Fig. 3 top). None of these AB can inhibit aminoethyldextran-induced trichocyst exocytosis (Fig. 3 bottom). This is in contrast to $\mathrm{AB}$ previously prepared against whole cclls which were shown to inhibit exocytosis by crosslinking components at sites of trichocyst exocytosis [45]. This may indicate that proteins extracted in the present study are not directly relevant for stimulated exocytosis, but that they rather belong to glycocalyx components characterized in the "Introduction". In EM analyses this is supported by the distance of most gold grains from the cell membrane (see below).

\section{CLSM fluorescence labeling}

Anti-nSAg AB stain the entire cell surface, including cilia on the "somatic" (outside cytostome) cell surface (Fig. 4a-c) and in the cytostome (Figure 4c), while any intracellular structures 

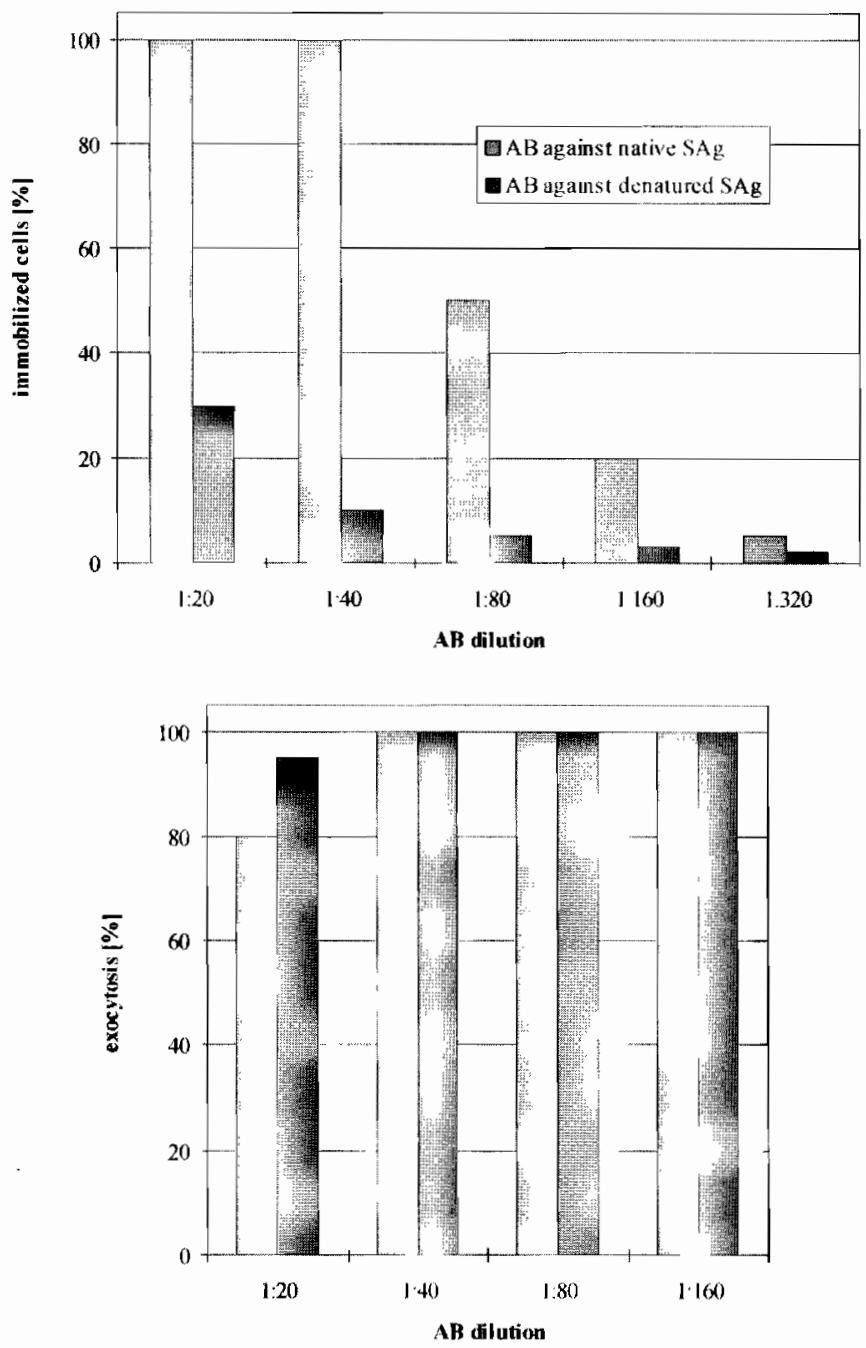

Fig. 3. Effect of $\mathrm{AB}$ against $\mathrm{nSAg}$ or dSAg, respectively, on cell immobilization (top) and triggered exocytosis (bottom), respectively.

are barely labeled. In Figure $4 b$, indentations in vicinity of cilia may correspond to parasomal sacs, in agreement with EM analyses (see below). In Fig. 4c, a clump of intensely stained material fills a nascent digestive (food) vacuole, while after pinching off, vacuoles are hardly labeled by anti-nSAg $\mathrm{AB}$ (compare with Figure 4d, below).

Anti-dSAg AB stain the cell surface, including cilia, mostly less than anti-nSAg AB (compare, e.g., Figure 4e with Figure $4 \mathrm{c}$ ), but now the contents of mature digestive vacuoles are stained (Fig. 4d). Even more brilliantly labeled are the cytoproct (not shown) and small vesicles $(\leq 1 \mu \mathrm{m})$ surrounding it (Fig. 4e), while no comparable labeling occurs in the cytostomal region, including the site of digesting vacuole formation.

In conclusion, we obtained differential labeling with the two $A B$ used. Although they both label the cell surface, labeling intensity achieved with anti-nSAg $\mathrm{AB}$ is more intense. In all cases, surface labeling is regularly distributed. The intracellular labeling described above, particularly that of food vacuoles after pinching off, clearly indicates sufficient specifieity of anti-dSAg $A B$ to trace preferentially degradative pathways (see also EM results, below, and "Discussion").

\section{Gold-labeling of PLT-unicryl sections}

Results achieved with anti-nSAg pA-gold conjugates on unicryl sections are presented in Figure 5. In most instances, the cell surface. including cilia around the cell and in the oral cavity, is homogenously labeled (Fig. 5a). Gold grains decorate the cell surface at a ccrtain distance, up to $50 \mathrm{~nm}$, in agreement with glycocalyx labeling. Gold label over the cytoplasm, including ill defined ER cisternae and small vesicles, is significantly above background, as quantified in Table I. Labeling achieved with both $\mathrm{AB}$ types reflects some cross-reactivity, but in any case Iabeling density is well above that over "negative reference structures" (mitochondria, trichocysts) and even more above off-cell background.

For the following organclles, presented in Figure 5, precise quantitation was not possible due to small size and too rare occurrence, though they are regularly and, hence, probably specifically labeled. Wc show this with anti-nSAg AB-gold conjugates for the following organelles, (i) terminal cisternae and associated vesicles (Fig. 5a), (ii) stacks of cisternae, also situated beneath ciliary basal bodics (Fig. 5a), (iii) Golgi fields, including membrane stacks and vesicles with a nonbristle-type coat (Fig. 5b) as described by Garreau De Loubresse [31], (iv) a reticular compartment with associated vesicles in vicinity of parasomal sacs (Fig. 5c) and, finally, (v) parasomal sacs themselves (Fig. 5c). Functional connections between these compartments are not yet thoroughly understood, since, for instance, in Paramecium terminal cisternae are considered early endosomes [3, 4], while in Tetrahymena they were interpreted as part of the Golgi apparatus [59]. The situation is intriguing indeed since in close vicinity of ciliary basal bodies and nearby parasomal sacs we find not only individual "terminal cisternae" (Fig. 5a, right). but sometimes multiple cisternae (Fig. 5a, left) and not too far away the reticular compartment with small vesicles (Fig. 5c) and genuine Golgi stacks (Fig. 5b). Only the latter can be clearly defined as Golgi fields.

Unfortunately, the structures just described are too small to be identified by CLSM, whereas this method can reveal occurrence of $\mathrm{dSAg}$ in food vacuoles and in discoidal vesicles (see Fig. 4d, e). In agreement with this, EM immuno-gold labeling analyses resulted in gold grain densities above background level (data nol shown).

Labeling densities achieved with both types of $\mathrm{AB}$ are compared in Table I.

\section{FRL labeling analysis}

This method lends itself to analyze membrane-bound label on the somatic cell membrane (Fig. 6a), on Golgi stacks (Fig. 6b), on the cell membrane in the oral cavity (Fig. 6c) and in parasomal sacs (Fig. 6d). Quantitation of labeling achicved with anti-

Fig. 4. CLSM immunolabeling analysis using anti-nSAg (a-c) or anti-dSAg (d,e) AB. Bars $=10 \mu \mathrm{m}$. (a) Note labeling of cell surface, including cilia. and absence of internal labeling. White central area represents cilia in oral cavity (oc). (b) Cell surface labeling encompasses cilia and nearby depressions, probably parasomal sacs (ps). (c) Cell surface labeling and oral cavity (oc) with intensely labeled nascent food vacuole (arrow). To its right is a faintly labeled cell surface region (produced by cell depression under the coverslip). (d) With anti-dSAg AB, note moderate labeling of cell surface, including oral cavity (oc) and labeling of food vacuoles (fv). (e) Brilliant labeling of small vesicles (v) which, in $\mathrm{z}$-series, are located adjacent to the cytoproct (not shown). 

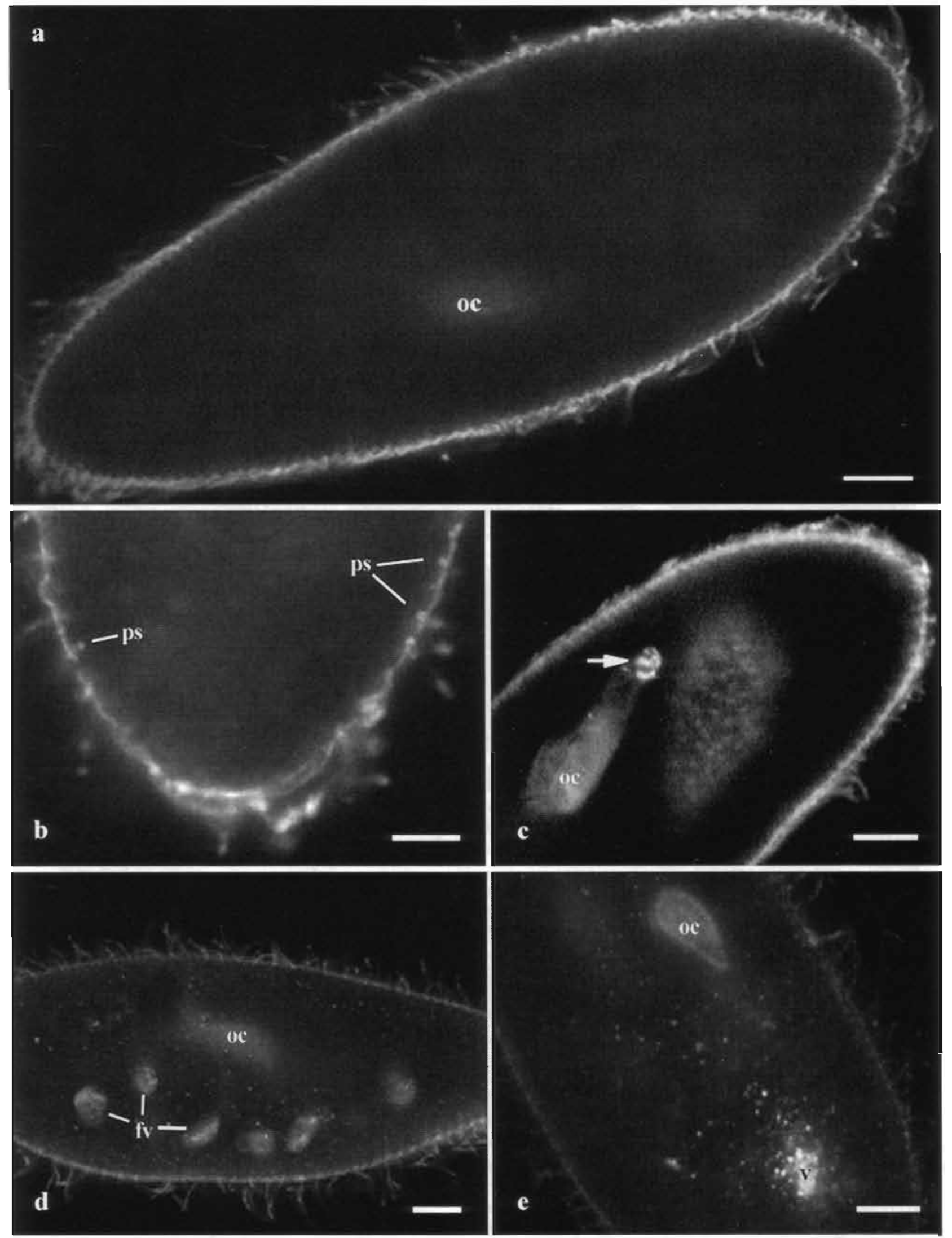

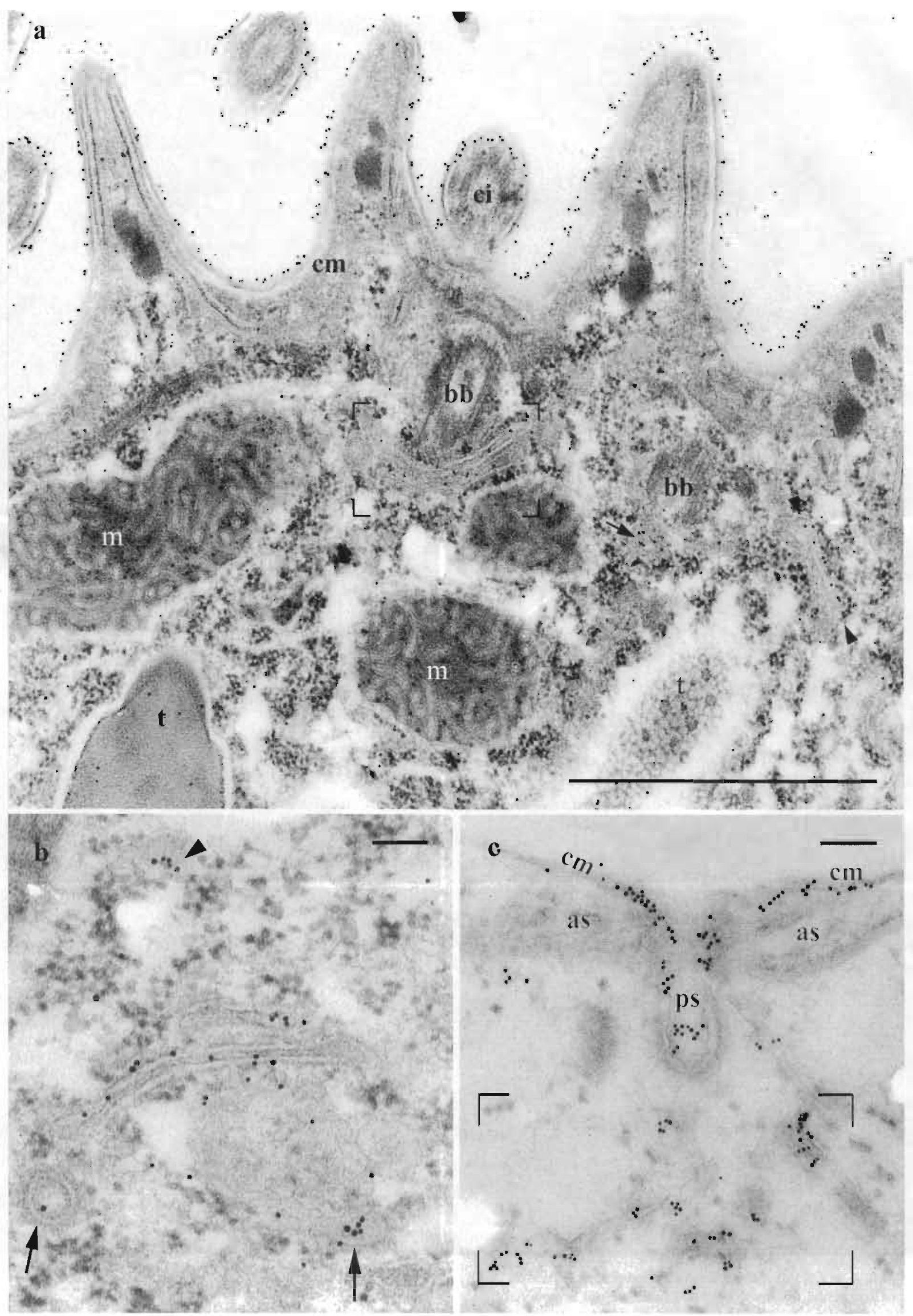
Tab. I. Labeling density (gold grains $/ \mu^{2}$ ) after (A) immuno-gold labeling of ultrathin unicryl sections or $(\mathbf{B})$ after freeze-fracture replica labeling (FRL).

\begin{tabular}{|c|c|c|}
\hline Structure analyzed & $\begin{array}{l}\text { (gold grains/ } / \mu m^{2} \\
\text { anti-nSAg } A B\end{array}$ & $\begin{array}{l}\left.{ }^{2}\right)+ \text { SEM } \\
\text { anti-dSAg AE }\end{array}$ \\
\hline \multicolumn{3}{|l|}{ (A) Section labeling } \\
\hline Off-cell background $(n=6)$ & $6.0 \pm 0.8$ & $5.8 \pm 2.3$ \\
\hline $\begin{array}{l}\text { Cell membrane/glycocalyx, } \\
50 \mathrm{~nm} \text { width, }(\mathrm{n}=11)\end{array}$ & $693.2 \pm 80.3$ & $372.3 \pm 33.4$ \\
\hline Trichocysts $(n=25)$ & $13.5 \pm 2.1$ & $9.4 \pm 5.3$ \\
\hline Mitochondria $(n=45)$ & $16.1 \pm 4.6$ & $13.9 \pm 2.3$ \\
\hline $\begin{array}{l}\text { Cytoplasm, including ER and } \\
\text { small vesicles }(n=10)\end{array}$ & $97.2 \pm 13.7$ & $71.5 \pm 6.9$ \\
\hline Digestive vacuoles $(n=5)$ & $149.0 \pm 23.5$ & $115.0 \pm 21.1$ \\
\hline $\begin{array}{l}\text { (B) Freeze-fracture labeling } \\
\text { Cell surface }(n=5)\end{array}$ & $725.0 \pm 18.0$ & $376.0 \pm 31.0$ \\
\hline
\end{tabular}

For more details of evaluations, see "Methods". SEM = standard error of the mean, $n=$ number of samples analysed.

$\mathrm{nSAg} \mathrm{AB}$ or anti-dSAg $\mathrm{AB}$, respectively, is remarkably close to that determined for ultrathin sections (Table I). Beyond this, FRL data reveal rather homogenous distribution of the antigens recognizcd in these membranes. Sincc samples were prepared by fast freezing, this is additional important and reliable information.

\section{Summary of results achieved}

The three widely different labeling methods used yielded compatible results (Table II). In addition, they complement cach other, since selective analysis of individual structures can be more easily and/or reliably achieved with one or the other approach. The biogenetic and degradative pathways derived therefrom are summarized in Figure 7 and will be discussed below.

\section{Discussion}

\section{The exocytotic biosynthetic pathway}

Our data show that cytoplasmic regions, containing ER and small vesicles, are labeled considerably above background. nSAg pass through the numerous dictyosomes [25, 31] corresponding to the number of randomly scattered intracellular fluorescent dots in CLSM analyses (data not shown).

In part, SAg in Tetrahymena resemble those in Paramecium [12], and these were found to resemble those in the widely different parasites, Trypanosoma [15] and Ichthyophthirius [20]. In Tetrahymena, delivery of SAg to the cell surface via dense

4 Fig. 5. Unicryl section labeling with anti-nSAg AB and pA-Au conjugate. Bars $=1 \mu \mathrm{m}$ (a) or $0.1 \mu \mathrm{m}(\mathbf{b}, \mathbf{c})$. In (a), note labeling of glycocalyx over somatic cell membrane $(\mathrm{cm})$ and cilia $(\mathrm{ci})$, of a triple membrane stack (boxed area, middle, with heavily labeled vesiclc at top left), of a clear vesicle (arrow) and of a flat cisterna (between arrowheads). These three labeled compartments are located in vicinity of ciliary basal bodies (bb). Some background label occurs over mitochondria (m) and trichocysts (t). In (b), a Golgi field displays labeling of cisternae (middle) and budding vesicles (arrow), as well as of a remote small clear vesicle (arrowhead). In (c), the cell surface $(\mathrm{cm}=$ cell membrane), a parasomal sac (ps) and an adjacent cisterna-like compartment with adjacent smaller compartments (all in boxed area), all display heavy labeling. Alveolar sacs (as) and any other structures are not labeled.
Tab. II. Comparison of relative labeling intensities obtained with different methods, using a(nti)-nSAg AB or a(nti)-d-SAg AB .

\begin{tabular}{lllllll}
\hline & \multicolumn{3}{c}{ CLSM } & \multicolumn{2}{c}{ sections } & FRL \\
\hline & a-nSAg & a-dSAg & a-nSAg & a-dSAg & a-nSAg a-dSAg \\
Cell surface & +++ & ++ & +++ & ++ & +++ & ++ \\
Cytoplasm & - & - & + & + & - & - \\
Food vacuole & & & & & & \\
$\quad$ nascent & +++ & - & $?$ & $?$ & $?$ & $?$ \\
$\quad$ mature & - & ++ & ++ & ++ & + & + \\
Parasomal sacs & ++ & - & ++ & - & ++ & - \\
Golgi/ER & $?$ & $?$ & ++ & $?$ & ++ & $?$ \\
Cytoproct & - & ++ & $?$ & $?$ & $?$ & $?$ \\
Discoidal ves. & - & - & - & + & $?$ & $?$ \\
\hline
\end{tabular}

$(-=$ no label $+=$ weak,$+=$ medium,$+++=$ strong label) "?" indicates that method applied is not suitable for analysis or that a certain structure was not recognized.

core vesicles (mucocysts) has been claimed [13]. We can exclude this, as also implied from recent genetic analyses with Tetrahymena [42]. False-positive signals in trichocysts after whole cell labeling may be due to $\mathrm{AB}$ binding by secretory lectins [35].

We conclude that those sites where parasomal sacs pinch off would also be the sites where SAg is inserted by constitutive exocytosis, particularly since we find clear vesicles reactive with anti-nSAg AB in this region, i.e. below parasomal sacs (Figs. 4b, 5c). How can this be reconciled with the presence of a bristle coat, indicative solely of endocytosis? First, coincidence of exo- and endocytosis sites is not unusual. Second, endocytosis, e.g., in nerve terminals at $37^{\circ} \mathrm{C}$ may require $1 \mathrm{~min}$ [54], while in some other systems several minutes may be required for coated pit assembly at $25^{\circ} \mathrm{C}$ to $30^{\circ} \mathrm{C}[33,58]$. Only exo-endocytotic systems operating on a "kiss-and-run" basis, without clathrin assembly, may work faster [46]. In contrast, exocytosis requires orders of magnitude less time in Paramecium [47] as in other systems [6]. This renders recognition of exocytotic profiles at the same sites very unlikely even when they occur. A similar pathway has previously been proposed for material release in Euplotes $[60,61]$. Yet wc cannot totally exclude SAg insertion by some other, unidentified small vesicles. Theoretically release could occur by fusion with the cell membrane at any site where adjacent alveolar sacs are not tightly connected with each other by a "suture" (see "Results"). However, we could not realize any such situation.

Interestingly parasomal sac-like vesicles flanking cilia in the oral cavity [3] are not labeled by any of the AB used. Such vesicles [36] as well as nearby discoidal vcsicles [26] have been assumed to release materials for coagulating food particles, and we observe coagulation of native SAg in the cytostome. The contents of these vesicles could contain enzymes for detachment of SAg for subsequent phagocytosis and degradation (see below).

\section{The endocytotic and degradative pathway}

Our data indicate that coated pits ("parasomal sacs") all over the cell surface, but not in the oral cavity, may internalize SAg. Parasomal sacs display the same labeling density as the rest of the cell membrane. From parasomal sacs SAg would be delivered to terminal cisternae, located beneath ciliary basal bodies. This would be compatible with the assumption that they represent acidic early endosomes $[4,5,27]$. Since by acidification SAg may be denatured, this could explain labeling of terminal cisternae predominantly with anti-dSAg AB. 

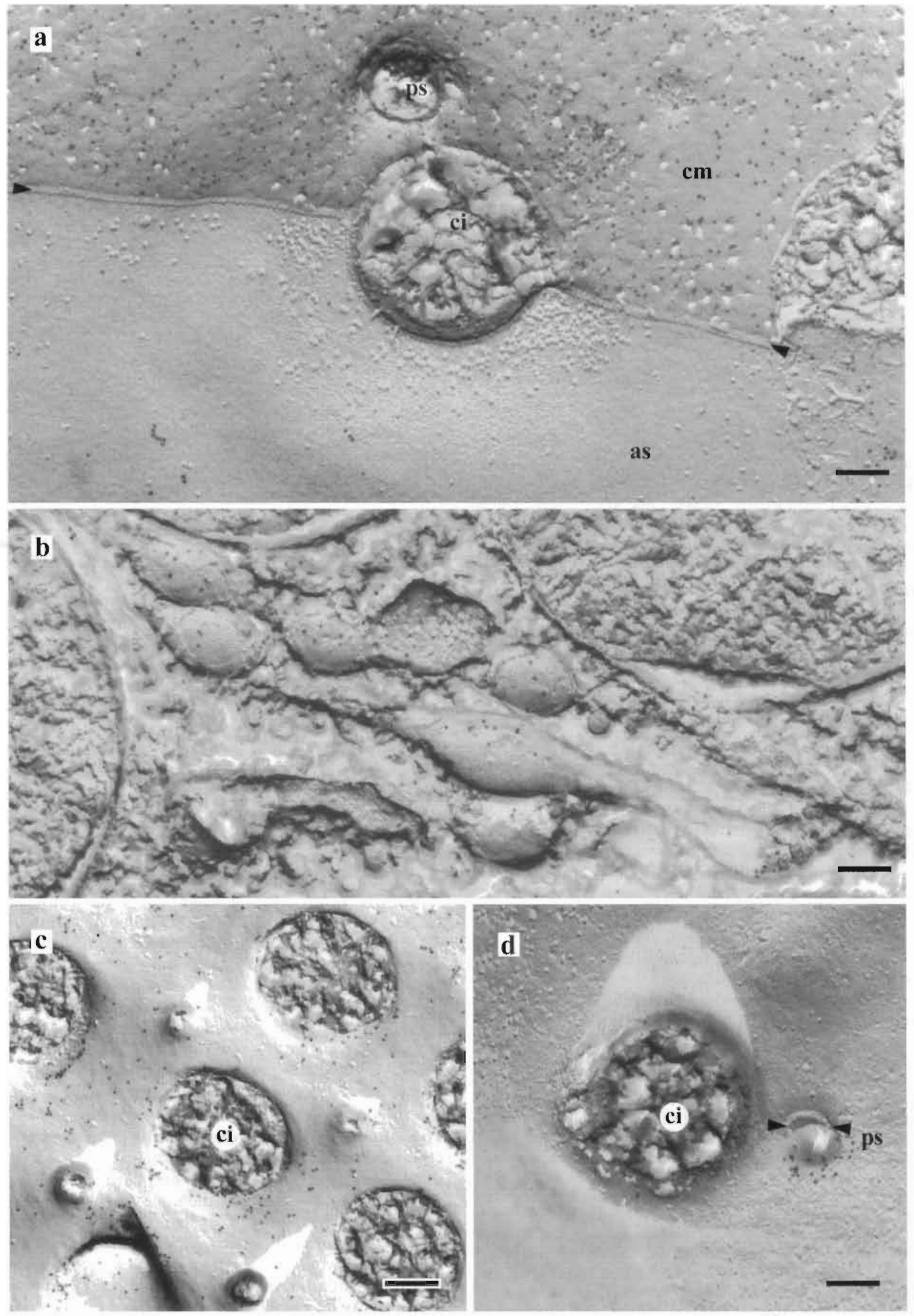
Fig. 6. FRL gold-labeling using anti-nSAg AB. Bars $=0.1 \mu \mathrm{m}$. In (a), the upper half is a fracture located in the cell membrane $(\mathrm{cm})$, which is split off in the lower half, thus exposing the outer membrane of an alveolar sac (as). Note selective labeling of the cell membrane (EF-face) and few gold grains in lower half (PF of alveolar sac membrane). The latter displays particles enriched around a ciliary basis (ci) and a suture-like connection (between arrowheads) to an adjacent sac (covered by the cell membrane). ps = parasomal sac. (b) Labeling of Golgi membranes (EF faces) in an area of typically small size (see text). (c, d) Document labeling of some selective cell membrane areas. (c) EF-fracture of an oral cavity with fractured bases of cilia (ci). (d) PF-fracture of a somatic cell membrane region, with broken ciliary basis (ci) and a parasomal sac (ps) which is heavily labeled because in this small indentation the outer fracture half of the cell membrane with its glycocalyx is retained (recognizable by the fracture ridge between arrowheads).

According to the scheme proposed in references [4, 27] for Paramecium (see Fig. 7), vesicular transport goes from terminal cisternae to digestive (food) vacuoles. These are phagolysosomes which are delivered to the cytoproct, followed by discharge of spent contents and membrane recycling via "discoidal vesicles" to the nascent food vacuole. Our evidence of the latter pathway is compatible with formation of food vacuoles also in the axenic medium [39] we used.

The second input of $\mathrm{SAg}$ into the degradative pathway occurs via the nascent digestive vacuole where $\mathrm{SAg}$ can be detected specifically by anti-nSAg AB (Fig. 4c). Rapid SAg denaturation is expected to occur due to rapid $\mathrm{pH}$ drop to $\sim 3.5$ after a vacuole is pinched off [28] causing labeling with anti-dSAg AB (Fig. 4d). Therefore, both internalization path ways described may contribute to a permanent turnover of $\mathrm{SAg}$ in the native state, rather than for elimination of denatured, degraded or "de-anchored" SAg. Tight occupancy of the entire cell surface with SAg may drive internalization at any endo-/phagocytotic site.
Finally we see, by CLSM analysis, selectively with antidSAg AB, labeling of small vesicles surrounding the cytoproct (Fig. 4e). According to PLT-unicryl section labeling these are discoidal vesicles (not shown). Therefore, a small amount of $\mathrm{SAg}$ may undergo re-uptake in the denatured state. Since in CLSM the areas surrounding cytoproct, oral cavity and nascent food vacuole are not labeled by anti-nSAg AB, these cell regions do not seem to be involved in SAg delivery to the cell surface, but rather in the degradative pathway.

\section{Conclusions}

We now can trace delivery to the cell surface by a classical secretory route via the Golgi apparatus. We exclude dense core vesicles and, therefore, imply constitutive exocytosis. We show two sites of uptake of SAg in native state, i.e., via parasomal sacs and via nascent food vacuoles. As to the superposition of the endo- and exocytotic pathway derived from our results, we tentatively givc the following interpretation. Intense gold labeling with anti-nSAg AB may identify center stage regions in the cell cortex (below ciliary bases), involving the Golgi apparatus (Fig. 5b) and a trans-Golgi network for delivery of nSAg to the cell surface, probably via small, clear secretory vesicles of the inconspicuous constitutive type (Fig. 5c). This route will be crossed by endocytotic vesicles pinching off at sites normally occupied by bristle-coated parasomal sacs (Fig. $5 \mathrm{c}$ ).

Uptake of GPI-anchored SAg has been assumed to involve cleavage by a GPI-specific phospholipase C, PL-C [15, 17]. While immunolabeling during shift from one SAg type to another resulted in spotty surface labeling [7], this can hardly be explained by activity of a PL-C at the cell surface, since exogenous enzymes do not detach GPI-anchored SAg components (data not shown). Though an equivalent enzyme may occur in Paramecium [8] its intracellular localization and function could not be established as yet.

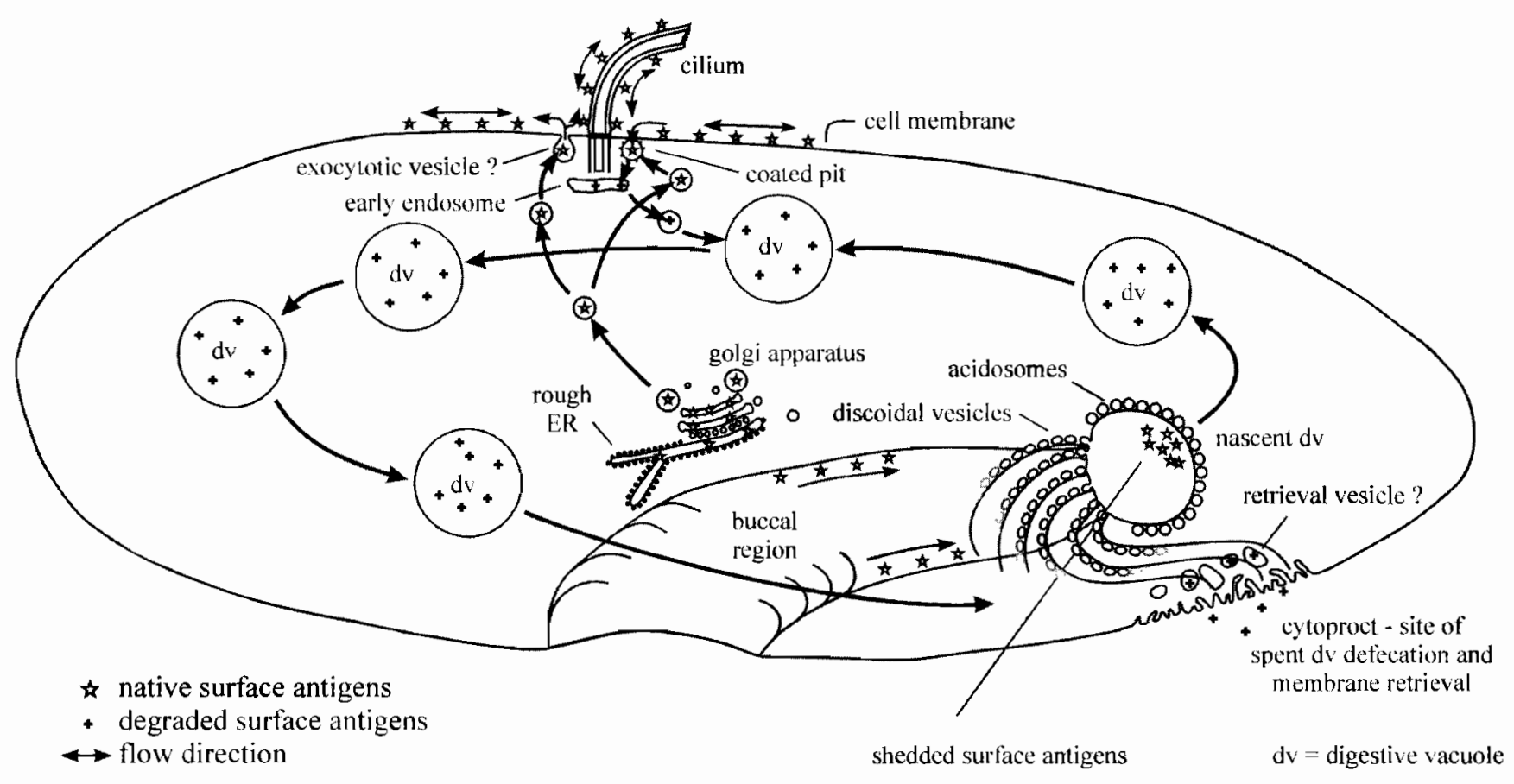

Fig. 7. Scheme of biosynthetic and degradative pathways of SAg. For references and further explanation, see text. 
Recent findings on potential effects of GPI-anchoring are as follows. In Toxoplasma, this does not cause higher turnover [56], while in pancreatic acinar cells detachment from the GPI anchor increases turnover of GP2 surface protein, but not of alkaline phosphatase, by endocytosis [29]. In our system, one potential site of release of $\mathrm{SAg}$ components from a GPI anchor could be terminal cisternae, another one the nascent food vacuole. A rather likely site would be the cytopharyngeal region, since the nascent food vacuole contains a rather compact mass of evidently shed SAg which is selectively labeled by anti-nSAg AB. Hence, SAg would be detachcd here in its native state from the cell membrane for internalization and degradation. Possibly clear vesicles aligned on the cytostomal cell membrane (see above) might serve such a function. The enzyme(s) involved remain to be established, be it GPIspecific PL-C or proteases. Remarkably in GPI-PL-C null mutants of Trypanosoma brucei, SAg variation and infectivity was unaffected [62].

Acknowledgements. We thank Ms. Edda Dassler for photographic artwork. Supported by Deutsche Forschungsgemeinschaft, SFB156/B4.

\section{References}

[1] Adoutte, A., K. Y. Ling, S. Chang, F. Huang, C. Kung: Physiological and mutational protein variations in the ciliary membrane of Paramecium. Exp. Cell Res. 148, 387-404 (1983).

[2] Adoutte, A., R. Ramanathan, R. M. Lewis, R. R. Dute, K. Y. Ling, C. Kung, D. L. Nelson: Biochemical studies of the excitable membrane of Paramecium tetraurelia. III. Proteins of cilia and ciliary membranes. J. Cell Biol. 84, 717-738 (1980).

[3] Allen, R. D.: Cytology. In: H.D. Görtz (ed.): Paramecium. pp. 4-40. Springer-Verlag, Berlin, Heidelberg, New York 1988.

[4] Allen, R. D., A. K. Fok: Endosomal membrane traffic of ciliates. In: H. Plattner (ed.): Membrane Traffic in Protozoa. pp. 283-309. JAI Press Inc., Greenwich (CT), London 1993.

[5] Allen, R. D., C. C. Schroeder, A. K. Fok: Endosomal system of Paramecium: coated pits to early endosomes. J. Cell Sci. 101, 449-461 (1992).

[6] Almers, W.: Exocytosis. Annu. Rev. Physiol. 52, 607-624 (1990).

[7] Antony, C., Y.Capdeville: Uneven distribution of surface antigens during antigenic variation in Paramecium primaurelia. J. Cell Sci. 92, 205-215 (1989).

[8] Assouz, N., Y.Capdeville: Structural comparisons between the soluble and the GPI-anchored forms of the Paramecium temperature-specific $156 \mathrm{G}$ surface antigen. Biol. Cell 75, 217-223 (1992).

[9] Assouz, N., B. Striepen, P. Gerold, Y. Capdeville, R. T. Schwarz: Glycosylinositol-phosphoceramide in the free-living protozoan Paramecium primaurelia: modification of core glycans by mannosyl phosphate. EMBO J. 14, 4422-4433 (1995).

[10] Barnett, A., E. Steers: Antibody-induced membrane fusion in Paramecium. J. Cell Sci. 65, 153-162 (1984).

[11] Benwakrim, A., A. Trémolière, J. Labarre, Y. Capdeville: The lipid moiety of the GPI-anchor of the major plasma membrane proteins in Paramecium primaurelia is a ceramide: Variation of the amide-linked fatty acid composition as a function of growth temperature. Protist 149, 39-50 (1998).

[12] Bleyman, L. K.: Ciliate genetics. In: K. Hausmann, P. C. Bradbury (eds.): Ciliates. Cells and Organisms. pp. 291-324. Gustav Fischer Verlag, Stuttgart, Jena 1996.

[13] Bolivar, I., J. Guiard-Maffia: Cellular localization of the serH surface antigen in Tetrahymena thermophila. J. Cell Sci. 94, 343-354 (1989).
[14] Brugerolle, G., C. Andrivon, J. Bohatier: Isolation, protein pattern and enzymatic characterization of the ciliary membrane of Paramecium tetraurelia. Biol. Cell 37, 251-260 (1980).

[15] Capdeville, Y., T. Baltz, C. Deregnaucourt, A. M. Keller: Immunological evidence of a common structure between Paramecium surface antigens and Trypanosoma variant surface glycoproteins. Exp. Cell Res. 167, 75-86 (1986).

[16] Capdeville, Y., A. Benwakrim: The major ciliary membrane proteins in Paramecium primaurelia are all glycosylphosphatidylinositol-anchored. Eur. J. Cell Biol. 70, 339-346 (1996).

[17] Capdeville, Y., F. Caron, C. Antony, C. Deregnaucourt, A. M. Keller: Allelic antigen and membrane-anchor epitopes of Paramecium primaurelia surface antigens. J. Cell Sci. 88, 553-562 (1987).

[18] Capdeville, Y., R. Charret, C. Antony, J. Delorme, P. Nahon, A. Adoutte: Ciliary and plasma membrane proteins in Paramecium: description, localization, and intracellular transit. In: $\mathrm{H}$ Plattner (ed.): Membrane Traffic in Protozoa. pp. 181-226. JAI Press Inc. Greenwich (CT), London 1993.

[19] Clark, T. G., H. W. Dickerson: Antibody-mediated effects on parasite behavior: evidence of a novel mechanism of immunity against a parasitic protist. Parasitol. Today 13, 477-480 (1997).

[20] Clark, T. G., T. L. Lin, H. W. Dickerson: Surface immobilization antigens of Ichthyophthirius multifiliis: their role in protective immunity. Annu. Rev. Fish Dis. 5, 113-131 (1995).

[21] Deregnaucour1, C.: Turnover of the GPI-anchored surface antigen in Paramecium. Partial release of its acylated form into the culture medium. Eur. J. Protistol. 28, 220-225 (1992).

[22] Deregnaucourt, C., A. M. Keller, Y. Capdeville: A new class of Paramecium surface proteins anchored in the plasma membrane by a glycosylinositol phospholipid. Membrane anchor of Paramecium cross-reacting glycoproteins. Biochem. J. 253, 395-400 (1988).

[23] Duszenko, M., A. Seyfang: Endocytosis and intracellular transport of variant surface glycoproteins in trypanosomes. In: H. Plattner (ed.): Membrane Traffic in Protozoa. pp. 227-258. JAI Press Inc., Greenwich (CT), London 1993.

[24] Eisenbach, L., R. Ramanathan, D. L. Nelson: Biochemical studies of the excitable membrane of Paramecium tetraurelia. IX. Antibodies against ciliary membrane proteins. J. Cell Biol. 97, 1412-1420 (1983).

[25] Estève, J. C.: L'appareil de Golgi des ciliés. ultrastructure, particulièrement chez Paramecium. J. Protozool. 19, 609-618 (1972).

[26] Estève, J. C.: Particularité du revètement cellulaire chez le cilié Paramecium caudalum. Le complexe cytopharynx-sac vacuolaire. Protistologica 16, 305-314 (1980).

[27] Fok, A. K., R. D. Allen: Membrane flow in the digestive cycle of Paramecium. In: H. Plattner (ed.): Membrane Traffic in Protozoa. pp. 311-337. JAI Press Inc., Greenwich (CT), London 1993.

[28] Fok, A. K., M. S. Ueno, E. A. Azada: Rapid and sensitive assays for phagosomal acidification in Paramecium and Tetrahymena. Eur. J. Cell Biol. 38, 306-311 (1985).

[29] Freedman, S. D., H. F. Kern, G. A. Scheele: Cleavage of GPIanchored proteins from the plasma membrane activates apical endocytosis in pancreatic acinar cells. Eur. J. Cell Biol. 75, 163-173 (1998).

[30] Fujimoto, K.: SDS-digested freeze-fracture replica labelling electron microscopy to study the two-dimensional distribution of integral membrane proteins and phospholipids in biomembranes: Practical procedure, interpretation and application. Histochem. Cell Biol. 107, 87-96 (1997).

[31] Garreau De Loubresse, N.: Early steps of the secretory pathway in Paramecium: ultrastructural, immunocytochemical, and genetic analysis of trichocyst biogenesis. In: H. Plattner (ed.): Membrane Traffic in Protozoa. pp. 27-59. JAI Press Inc., Greenwich (CT), London 1993.

[32] Gerold, P., L. Vivas, S. A. Ogun, N. Azzouz, K. N. Brown, A. A. Holder, R. T. Schwartz: Glycosylphosphatidylinositols of Plasmodium chabaudi chabaudi: a basis for the study of malarial glycolipid toxins in a rodent model. Biochem. J. 328, 905-911 (1997). 
[33] Gilbert, A., J. P. Paccaud, J. C. Carpentier: Direct measurement of clathrin-coated vesicle formation using a cell-free assay. J. Cell Sci. 110, 3105-3115 (1997).

[34] Gulik-Krzywicki, T., M. J. Costello: The use of low temperature $x$-ray diffraction to evaluate freezing methods used in freezefracture electron microscopy. J. Microse. (Oxford) 112, 103-114 (1978).

[35] Haacke-Bell, B., H. Plattner: Secretory lectins contained in trichocyst tips of Paramecium. Eur. J. Cell Biol. 44, 1-9 (1987).

[36] Jahn, T. L., E. C. Bovee, M. Dauber, H. Winet, M. Brown: Secretory activity of the oral apparatus of ciliates: trails of adherent particles left by Paramecium multimicronucleatum and Tetrahymena pyriformis. Ann. N.Y. Acad. Sci. 118, 912-920 (1965).

[37] Jones, I. G.: Studies on the characterization and structure of the immobilization antigens of Paramecium aurelia. Biochem. J. 96, $17-23$ (1965).

[38] Kaneshiro, E. S., L. S. Beischel, S. J. Merkel, D. E. Rhoads: The fatty acid composition of Paramecium tetraurelia cells and cilia: changes with culture age. J. Protozool. 26, 147-158 (1979).

[39] Kaneshiro, E. S., S. F. Reuter, F. J. Quattrone, R. E. Morris: Sustained food vacuole formation by axenic Paramecium tetraurelia and the inhibition of membrane recycling by Alcian blue. J. Protozool. 39, 713-718 (1992).

[40] Kissmehl, R., K. Hauser, M. Gössringer, M. Momayezi, N Klauke, H. Plattner: Immunolocalization of the exocytosissensitive phosphoprotein, PP63/parafusin, in Paramecium cells using antibodies against recombinant protein. Histochem. Cell Biol. 110, I-8 (1998).

[41] Knochel, M., R. Kissmehl, J. D. Wissmann, M. Momayezi, J. Hentschel, H. Plattner, R. D. Burgoyne: Annexins in Paramecium cells. Involvement in site-specific positioning of secretory organelles. Histochem. Cell Biol. 105, 269-281 (1996).

[42] Melia, S. M., E. S. Cole, A. P. Turkewitz: Mutational analysis of exocytosis in Tetrahymena. J. Cell Sci. 111, 131-140 (1998).

[43] Merkel, S. J., E. S. Kaneshiro, E. I. Gruenstein: Characterization of the cilia and ciliary membrane proteins of wild-type Paramecium tetraurelia and a pawn mutant. J. Cell Biol. 89, 206-215 (1981).

[44] Miller, L. H., M. F. Good, G. Milon: Malaria pathogenesis. Science (Wash., DC) 264, 1878-1883 (1994).

[45] Momayezi, M., A. Girwert, C. Wolf, H. Plattner: Inhibition of exocytosis in Paramecium cells by antibody-mediated crosslinking of cell membrane components. Eur. J. Cell Biol. 44, 247-257 (1987).

[46] Palfrey, H. C., C. R. Artalejo: Vesicle recycling revisited: rapid endocytosis may be the first step. Neuroscience 83, 969-989 (1998).

[47] Plattner, H., G. Knoll, R. Pape: Synchronization of different steps of the secretory cycle in Paramecium tetraurelia: trichocyst exocytosis, exocytosis-coupled endocytosis, and intracellular transport. In: H. Plattner (ed.): Membrane Traffic in Protozoa. pp. 123-148. JAl Press Inc., Greenwich (CT), London 1993.
[48] Plattner, H., H. P. Zingsheim: Electron microscopic methods in cellular and molecular biology. Subcell. Biochem. 9, 1-236 (1983).

[49] Prat, A., M. Katinka, F. Caron, E. Meyer: Nucleotide sequence of the Paramecium primaurelia $\mathrm{G}$ surface protein with a highly periodic structure. J. Mol. Biol. 189, 47-60 (1986).

[50] Preer, J. R.: Studies on the immobilization antigens of Paramecium. II. Isolation. J. Immunol. 83, 378-384 (1959).

[51] Preer, J. R., L. B. Preer, B. M. Rudman: mRNAs for the immobilization antigens of Paramecium. Proc. Natl. Acad. Sci. USA 78, 6776-6778 (1981).

[52] Preer, J. B., L. B. Preer, B. Rudman, A. Barnett: Molecular biology of the genes for immobilization antigens in Paramecium. J. Protozool. 34, 418-423 (1987).

[53] Ramanathan, R., Y.Saimi, J. B. Peterson, D. L. Nelson, C. Kung: Antibodies to the ciliary membrane of Paramecium tetraurelia alter membrane excitability. J. Cell Biol. 97, 1421-1428 (1983).

[54] Ryan, T. A., S. J. Smith: Vesicle pool mobilization during action potential firing at hippocampal synapses. Neuron 14, 983-989 (1995).

[55] Schmidt, H. J.: Immobilization antigens. In: H. D. Görtz (ed.): Paramecium. pp. 155-166. Springer-Verlag Berlin, Heidelberg, New York 1988.

[56] Seeber, F., J.F. Dubremetz, J.C. Boothroyd: Analysis of Toxoplasma gondii stably transfected with a transmembrane variant of its major surface protein, SAG1. J. Cell Sci. 11, 23-29 (1998).

[57] Sonneborn, T. M.: The Paramecium aurelia complex of 14 sibling species. Trans. Am. Microsc. Soc. 94, 155-178 (1975).

[58] Thilo, L., C. De Chastellier: Enzymatic labeling of cell-surface glycoproteins as an autoradiographic probe for morphometric analysis of intracellular membrane traffic. In: H. Plattner (ed.): Electron Microscopy of Subcellular Dynamics. pp. 165-178. CRC Press Inc., Boca Raton (FL) 1989.

[59] Tiedtke, A., T. Kiy, C. Vosskühler, L. Rasmussen: Pathways of lysosomal enzyme secretion in Tetrahymena. In: H. Plattner (ed.): Membrane Traffic in Protozoa. pp. 99-122. JAI Press Inc., Greenwich (CT), London 1993.

[60] Verni, F., G. Rosati, P. Luporini: Preconjugant cell-cell interaction in the ciliate Euplotes crassus: a possible role of the ciliary ampules. J. Exp. Zool. 204, 171-179 (1978).

[61] Verni, F., G. Rosati, P. Luporini: Activity of the ciliary ampules through successive stages of the ciliate Euplotes crassus. Experientia 37, 42-44 (1981).

[62] Webb, H., N. Carnall, L. Vanhamme, S. Rolin, J. Van Den Abbeele, S. Welburn, E. Pays, M. Carrington: The GPI-phospholipase $\mathrm{C}$ of Trypanosoma brucei is noncssential but influences parasitemia in mice. J. Cell Biol. 139, 103-I14 (1997). 